
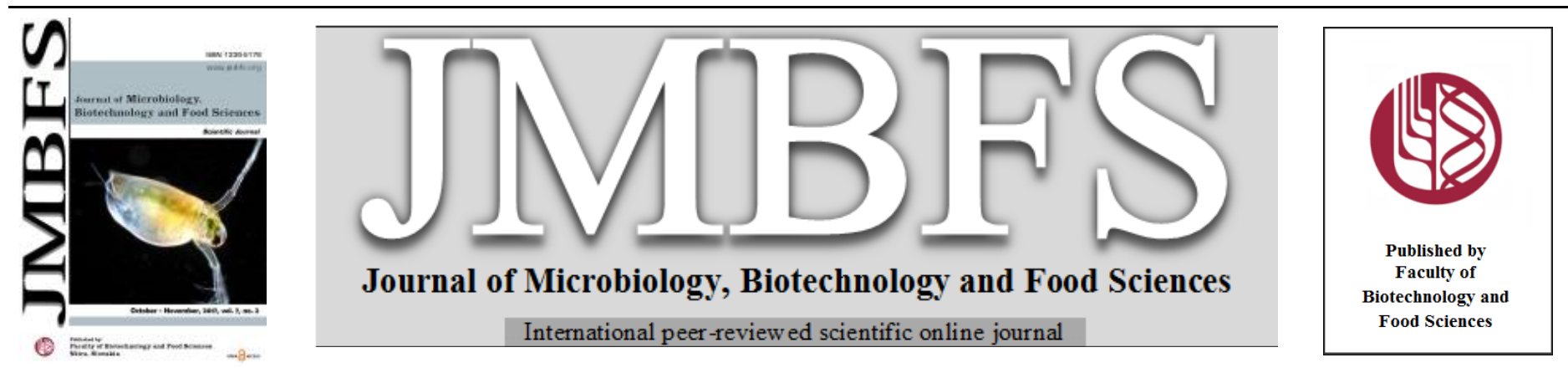

\title{
INFLUENCE OF GLUCOSE AND L-ASPARAGINE CONCENTRATIONS ON L-ASPARAGINASE PRODUCTION BY ENDOPHYTIC FUNGI
}

\author{
Yiing Yng Chow ${ }^{l}$ and Adeline Su Yien Ting ${ }^{l}$ \\ Address(es): \\ ${ }^{1}$ School of Science, Monash University Malaysia, 46150 Bandar Sunway, Selangor, Malaysia.
}

*Corresponding author: adeline.ting@monash.edu; adelsuyien@yahoo.com

doi: 10.15414/jmbfs.2017.7.2.186-189

\section{ARTICLE INFO}

Received 17. 8. 2016

Revised 6. 6. 2017

Accepted 20. 9. 2017

Published 1. 10. 2017

Regular article

OPEN $\partial_{\text {ACCESS }}$

\begin{abstract}
In this study, five L-asparaginase-producing endophytes (ODL4, PBS1, PBL13, CCL1, MKS1) were evaluated for their L-asparaginase production when cultivated in various glucose $(0,0.5,1,2,3,4,5 \%)$ and L-asparagine $(0,5,10,20,30,40,50 \mathrm{mM})$ concentrations over a period of 20 days. L-asparaginase production was quantified via Nesslerization and expressed as L-asparaginase activities. Results revealed supplementation with nitrogen-source (L-asparagine) induced higher L-asparaginase activities compared to carbonsource (glucose), with means of 0.106 compared to $0.062 \mu \mathrm{M} \mathrm{mL}^{-1} \mathrm{~min}^{-1}$, respectively. The optimum concentration of L-asparagine was $30 \mathrm{mM}$. On the contrary, optimum levels for glucose was inconclusive. Among the isolates, isolate MKS1 produced the highest Lasparaginase activities when supplemented with $5 \%$ glucose and $10 \mathrm{mM}$ asparagine. This study revealed that nitrogen-based source (Lasparagine) is more effective than carbon-source (glucose) in inducing L-asparaginase activities.
\end{abstract}

Keywords: L-asparagine concentration; endophyte; glucose concentration; L-asparaginase production; medicinal plant

\section{INTRODUCTION}

L-asparaginase (E.C.3.5.1.1) is an enzyme that catalyzes the hydrolysis of Lasparagine to L-aspartate and ammonia (Theantana et al., 2009). As an anticancer agent, L-asparaginase removes the L-asparagine in the blood, depriving tumor cells of L-asparagine, leading towards incapacitated cell division. L-asparaginase is an enzyme produced by animals, plants, yeasts and microorganisms (Sarquis et al., 2004). Among these, bacteria-produced Lasparaginase is the most extensively explored, due to their cost-effective nature (Theantana et al., 2009). Many of the commercially-produce L-asparaginase is derived from Escherichia coli, Erwinia carotovora and Serratia marcescens (Oza et al., 2010). L-asparaginase from these prokaryotic sources was however, discovered to cause allergic reactions and anaphylaxis. This led to investigations on L-asparaginase derived from eukaryotic microorganisms such as fungi. In recent years, several fungal species have been identified as promising producers of fungal-derived L-asparaginase, which include Aspergillus nidulans, A. niger and Cylindrocarpon obtusisporum MB-10 (Raha et al., 1990), in which the Lasparaginase produced do not cause allergy and are safer to use (Patil et al., 2012).

In this study, the endophytes with potential for production of L-asparaginase were isolated from medicinal plants with anticancer properties (Chow and Ting, 2015). Endophytes from medicinal plants are explored as it has been hypothesized that they may have the ability to produce certain metabolites, which are similar to their host plants, exemplified by the discovery of taxol produced by the endophytic Taxomyces andrenae (Newmann and Cragg, 2007). Literatures have documented that the early studies on L-asparaginase production by endophytes were generally focused on the identification of endophytic species and the quantification of their L-asparaginase production (Raha et al., 1990; Sarquis et al., 2004; Theantana et al., 2009; Oza et al., 2010; Chow and Ting, 2015). Studies on optimizing L-asparaginase production as attempted in this study, is fairly new, but is crucial to aid in the mass production of L-asparaginase for pharmaceutical and medical applications.

Several factors were reportedly influential in the production of L-asparaginase, namely nutritional factors, temperature and $\mathrm{pH}$ (Chakravarti and Sahai, 2002; Hermanto and Ting, 2016). Among these, nutritional factor is the most important as fungal growth is primarily dependent on nutrients. The most extensively studied aspect on nutritional influence is the impact of various types of carbon and nitrogen sources on production of L-asparaginase. In this study, our objective is to screen for the effect of various carbon and nitrogen sources on production of L-asparaginase, and to determine the optimum concentration for each nutritional source. To achieve this, glucose (carbon source) and Lasparagine (nitrogen source) was pre-determined as the two nutrients as they are less studied compared to other sources. The concentrations were varied and production of L-asparaginase (expressed as L-asparaginase activities) by endophytic isolates was reported.

\section{MATERIAL AND METHODS}

\section{Isolate preparation}

Five endophytic isolates; strain ODL4 (Ascomycota sp., accession number KM104579) from Oldenlandia diffusa; strain PBS1 (Dothideomycetes sp., accession number KM104575) and strain PBL13 (Penicillium simplicissimum accession number KM104597) from Pereskia bleo; strain CCL1 (Dothideomycetes sp., accession number KM104577) from Cymbopogon citratus; strain MKS1 (Fusarium oxysporum, accession number KM104584) from Murraya koenigii, were isolated and identified using universal primers ITS1 and ITS4 (Chow and Ting, 2015). Their sequences were deposited in NCBI and the accession numbers (KMseries) obtained. These five isolates had showed relatively high L-asparaginase activities in an earlier study (Chow and Ting, 2015), suggesting strong potential for up-scaling to mass produce the valuable enzyme. The isolates were cultured and maintained on Potato Dextrose Agar (PDA) and incubated at $28 \pm 2{ }^{\circ} \mathrm{C}$ for $7-14$ days.

\section{$L$-asparaginase production under the influence of $L$-asparagine}

The fungal cultures were first initiated by inoculating 5 mycelial plugs from 7 day old cultures into $50 \mathrm{~mL}$ centrifuge tube containing $30 \mathrm{~mL}$ of Minimal Media, varied accordingly with different concentrations of L-asparagine for each tube $(0$, $5,10,20,30,40$ and $50 \mathrm{mM})$. The cultures were incubated at $37 \pm 2{ }^{\circ} \mathrm{C}$ with agitation (120 rpm) for 20 days. L-asparaginase activity was determined on day $1,3,5,7,9,11,13,15,17$ and 20, by performing the Nesslerization assay. For the assay, $100 \mu \mathrm{L}$ of broth was pipetted into $2 \mathrm{~mL}$ microcentrifuge tubes and mixed with $100 \mu \mathrm{L}$ of Tris HCL (pH 7.2), $200 \mu \mathrm{L}$ of $0.04 \mathrm{M}$ asparagine and 100 $\mu \mathrm{L}$ of sterile distilled water (SDW). The mixture was incubated at $37 \pm 2^{\circ} \mathrm{C}$ for $1 \mathrm{~h}$, followed by the addition of $100 \mu \mathrm{L}$ of $1.5 \mathrm{M}$ trichloroacetic acid (TCA) to stop the enzymatic reaction (Imada et al., 1973; Hermanto and Ting, 2016) Subsequently, $100 \mu \mathrm{L}$ of the mixture was transferred into fresh tubes containing $750 \mu \mathrm{L}$ SDW and $300 \mu \mathrm{L}$ of Nessler's reagent (Tan et al., 2005). Mixtures were incubated at $28 \pm 2{ }^{\circ} \mathrm{C}$ for $20 \mathrm{~min}$, after which the absorbance value of the 
mixtures was read at $450 \mathrm{~nm}\left(\right.$ TECAN $^{\circledR}$ Infite M200 Multi Detection Microplate Reader Part). The L-asparaginase activity was estimated from a standard curve generated from varying concentrations of ammonium sulfate $(0.1,0.2,0.3,0.4$, $0.5,0.6,0.7,0.8,0.9$ and $1.0 \mu \mathrm{M})$. One unit of L-asparaginase activity is expressed as the amount of enzyme that catalyzes the formation of $1 \mu \mathrm{mol}$ of ammonia per minute at $37 \pm 2{ }^{\circ} \mathrm{C}$ (Tan et al., 2005; Hermanto and Ting, 2016)

\section{L-asparaginase production under the influence of glucose concentrations}

The fungal cultures were prepared simialrly, by inoculating 5 mycelial plugs from 7-day old cultures into $50 \mathrm{~mL}$ centrifuge tube containing $30 \mathrm{~mL}$ of Minimal Media, supplemented with different concentrations of glucose $(0,0.5,1,2,3,4$ and $5 \%$ ) to determine the influence of glucose on L-asparaginase activities. The inoculated cultures were incubated at $37 \pm 2{ }^{\circ} \mathrm{C}$ with agitation $(120 \mathrm{rpm})$ for 20 days. The L-asparaginase activity was measured on day $1,3,5,7,9,11,13,15$, 17 and 20, via Nesslerization. The Nesslerization procedure was performed by first mixing $100 \mu \mathrm{L}$ of broth with $100 \mu \mathrm{L}$ of Tris $\mathrm{HCL}(\mathrm{pH} 7.2$ ), $200 \mu \mathrm{L}$ of 0.04 $\mathrm{M}$ asparagine and $100 \mu \mathrm{L}$ of sterile distilled water (SDW). The mixture was incubated at $37 \pm 2^{\circ} \mathrm{C}$ for $1 \mathrm{~h}$, followed by the addition of $100 \mu \mathrm{L}$ of $1.5 \mathrm{M}$ trichloroacetic acid (TCA) to stop the enzymatic reaction. The mixture $(100 \mu \mathrm{L})$ was then transferred into fresh tubes containing $750 \mu \mathrm{L}$ SDW and $300 \mu \mathrm{L}$ of Nessler's reagent, incubated at $28 \pm 2{ }^{\circ} \mathrm{C}$ for $20 \mathrm{~min}$, after which the absorbance value of the mixtures was read at $450 \mathrm{~nm}\left(\mathrm{TECAN}^{\circledR}\right.$ Infite M200 Multi Detection Microplate Reader Part). The L-asparaginase activity was estimated from a standard curve and one unit of L-asparaginase activity is expressed as the amount of enzyme that catalyzes the formation of $1 \mu \mathrm{mol}$ of ammonia per minute at $37 \pm 2$ ${ }^{\circ} \mathrm{C}$ as described in the previous section (Tan et al., 2005; Hermanto and Ting, 2016)

\section{Statistical analysis}

Triplicate was prepared for every assessment. The data was statistically analyzed using the software Statistical Package for the Social Sciences (SPSS) version 20.0. One-way ANOVA with Tukey's Studentized Range Test (HSD $(0.05)$ ) were applied to analyze all the data collected. Differences were considered significant at $\mathrm{p}<0.05$.

\section{RESULTS}

\section{L-asparaginase production by endophytes in response to L-asparagine concentrations}

Higher concentrations (10 to $50 \mathrm{mM}$ ) of L-asparagine stimulated L-asparaginase production in all endophytic isolates $\left(0.0508\right.$ to $0.1701 \mu \mathrm{M}^{-1} \mathrm{~mL}^{-1} \mathrm{~min}^{-1}$ of $\mathrm{L}$ asparaginase activities). These levels were significantly higher than levels detected from isolates cultured in the absence of $\mathrm{L}$-asparagine $(0 \mathrm{mM})(0.0124$ to $\left.0.0144 \mu \mathrm{M}^{-1} \mathrm{~mL}^{-1} \mathrm{~min}^{-1}\right)$ as shown in Fig 1. In Fig 1, it was observed that isolates PBS1 (Dothideomycetes sp.), MKS1 (F. oxysporum) and ODL4 (Ascomycota sp.) produced the highest L-asparaginase activities when supplemented with $20 \mathrm{mM}$ L-asparagine, as increase in concentrations $(30,40,50 \mathrm{mM})$ thereafter did not yield significant increase in L-asparaginase activities. Isolates CCL1 (Dothideomycetes sp.) and PBL13 (Penicillium simplicissimum) produced the highest L-asparaginase activities when supplemented with a minimum of $30 \mathrm{mM}$ of L-asparagine. Among the endophytic isolates tested, isolate MKS1 (Fusarium oxysporum) responded most positively to increasing concentrations of $\mathrm{L}$ asparagine. For this isolate, higher L-asparaginase activities of $0.038,0.061$, $0.111,0.142,0.159$ and $0.167 \mu \mathrm{M}^{-1} \mathrm{~mL}^{-1} \mathrm{~min}^{-1}$ were recorded when supplemented with $5,10,20,30,40$ and $50 \mathrm{mM}$ of L-asparagine, respectively, as compared to control $\left(0.013 \mu \mathrm{M}^{-1} \mathrm{~mL}^{-1} \mathrm{~min}^{-1}\right.$ at $\left.0 \mathrm{mM}\right)$. In the absence of L-asparagine, al isolates produced similar levels of L-asparaginase activities. Maximum Lasparaginase activities was achieved by the $7^{\text {th }}$ day. This is presumably the optimum incubation period for cultures supplemented with L-asparagine, as prolonged incubation thereafter did not result in significant increase in Lasparaginase activities (data not shown).

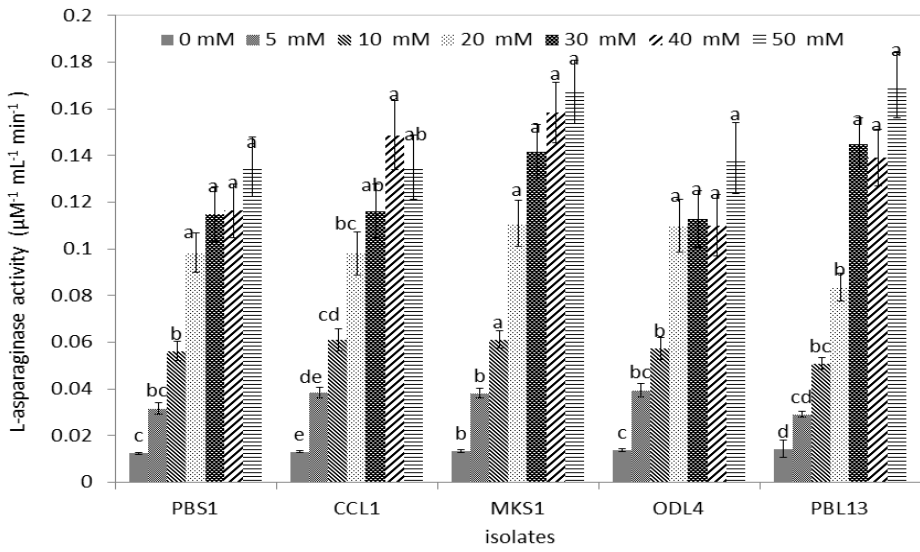

Figure 1 L-asparaginase activities $\left(\mu \mathrm{M}^{-1} \mathrm{~mL}^{-1} \mathrm{~min}^{-1}\right)$ of isolates PBS1 (Dothideomycetes sp.), CCL1 (Dothideomycetes sp.), MKS1 (Fusarium oxysporum), ODL4 (Ascomycota $\mathrm{sp}$.) and PBL13 (Penicillium simplicissimum) in response to L-asparagine concentrations $(0,5,10,20,30,40$ and $50 \mathrm{mM})$. Means with the same letters are not significantly different within same isolate as determined by Tukey's studentized range test $\left(\mathrm{HSD}_{0.05}\right)$. Vertical bars indicate standard errors.

\section{L-asparaginase production by endophytes in response to glucose concentrations}

From Fig 2, it was evident that supplementation with glucose enhanced Lasparaginase activities for all endophytic isolates. With a minimum concentration of $0.5 \%$ glucose, L-asparaginase activities were significantly increased in most endophytes (compared to control, 0\% glucose). Isolate MKS1 (Fusarium oxysporum) responded most positively to increasing concentrations of glucose, with $0.009,0.031,0.038,0.053,0.063,0.077$ and $0.089 \mu \mathrm{M}^{-1} \mathrm{~mL}^{-1} \mathrm{~min}^{-1}$ produced, in response to $0,0.5,1.0,2.0,3.0,4.0$ and $5.0 \%$ glucose, respectively. A similar trend was observed for isolate ODL4 (Ascomycota sp.) in response to increasing glucose concentrations. For both isolate MKS1 and ODL4, the isolates appeared to demonstrate continuous increase in L-asparaginase activities when increasing concentrations of glucose is supplemented. On the contrary, isolates PBS1 (Dothideomycetes sp.), CCL1 (Dothideomycetes sp.) and PBL13 (Penicillium simplicissimum) showed less significant increase in L-asparaginase activities when supplemented with glucose $(1-5 \%)$. For isolate PBS1 and PBL13, maximum L-asparaginase activities may have been achieved with supplementation of only $1 \%$ glucose as the activities did not differ significantly when PBS1 and PBL13 was cultured in 1-5\% glucose (Fig. 2). For isolate CCL1, maximum L-asparaginase activities was achieved with the supplementation of $3 \%$ glucose. Production of L-asparaginase peaked over a 7-day period for al isolates, irrespective of the concentrations. Prolonged incubation up to 20 days did not result in enhanced L-asparaginase activities (data not shown).

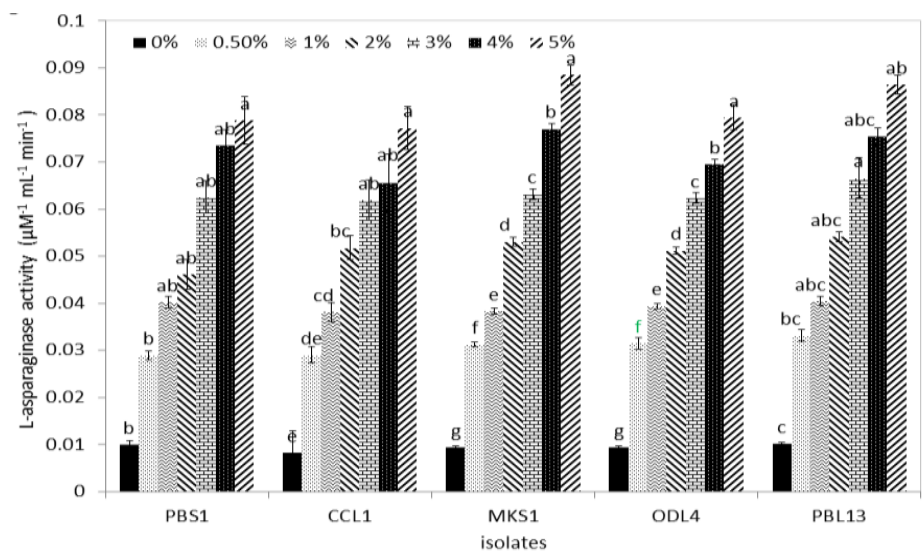

Figure 2 L-asparaginase activities $\left(\mu \mathrm{M}^{-1} \mathrm{~mL}^{-1} \mathrm{~min}^{-1}\right)$ of isolates PBS1 (Dothideomycetes sp.), CCL1 (Dothideomycetes sp.), MKS1 (Fusarium oxysporum), ODL4 (Ascomycota sp.) and PBL13 (Penicillium simplicissimum) in response to various glucose concentrations $(0,0.5,1,2,3,4$ and $5 \%)$. Means with the same letters are not significantly different within the isolate as determined by Tukey's studentized range test $\left(\mathrm{HSD}_{0.05}\right)$. Vertical bars indicate standard errors.

In short, glucose and L-asparagine were found to induce L-asparaginase activities in all endophytes, with higher activities detected when supplemented with Lasparagine ( 0.061 to $0.145 \mu \mathrm{M} \mathrm{mL} \mathrm{min}^{-1}$ ) compared to glucose $(0.040$ to 0.089 $\mu \mathrm{M} \mathrm{mL} \mathrm{min}^{-1} \mathrm{~min}^{-1}$. Among the isolates, isolate MKS1 (Fusarium oxysporum) responded most positively to supplementation of glucose and L-asparagine with 
relatively high levels of L-asparaginase activities. This established that MKS1 (Fusarium oxysporum) have the most potential for industrial production of $\mathrm{L}$ asparaginase, particularly when provided with L-asparagine at $10 \mathrm{mM}$ and above.

\section{DISCUSSION}

This study revealed several key findings. Firstly, production of L-asparaginase in endophytic isolates can be induced by glucose and L-asparagine supplementation as higher levels of L-asparaginase activities were detected. The amenability of endophytes to nutrient manipulation is crucial for the up-scaling production of valuable enzymes. It allows further exploration into harnessing valuable compounds from endophytes, especially with the promising trend in isolating novel endophytes from medicinal plants to derive novel antitumor, antimicrobial, antifungal and antioxidant compounds (Wiyakrutta et al., 2004; Eyberger et al., 2006; Kusari et al., 2008; Zhao et al., 2014), as well as valuable enzymes such as hydrolytic enzymes and L-asparaginase (Chow and Ting, 2015; Hermanto and Ting, 2016).

This study has demonstrated that the nitrogen source, in the form of Lasparagine, was influential and induced higher activities of L-asparaginase Synthesis of L-asparaginase is a nitrogen-regulated process (Sarquis $\boldsymbol{e t}$ al., 2004) as nitrogen is a key constituent of the various amino acids, nucleotides and coenzymes synthesized. Therefore, induced L-asparaginase production/activities by supplementation of nitrogen source (L-asparagine) is to be expected (Kenari et al., 2011). Of the various concentrations tested in this study, $20 \mathrm{mM}$ appeared to be the optimum concentration to induce L-asparaginase production in most endophytes. The positive influence of L-asparagine on the L-asparaginase activities was also observed in a separate study by Hermanto and Ting (2016) In their study, L-asparagine supplementation contributed to growth enhancement of a Fusarium endophyte (R19), which susbequently led to higher levels of Lasparaginase produced. The presence of L-asparagine is stipulated to have created a positive feedback mechnaism that enhanced L-asparaginase activities. This was observed in other species such as Aspergillus terreus MTCC1782 (Baskar and Renganathan, 2011) and Streptomyces albidoflavus (Narayana et al., 2008). On the contrary, production of L-asparaginase when supplemented with glucose was less predictable with few isolates (Fusarium oxysporum MKS1, Ascomycota sp. ODL4) demonstrating an increasing trend beyond the $5 \%$ glucose concentration tested. In fact, the influence of glucose on L-asparaginase activities is not well-studied. In this study, it was observed that higher activities of L-asparaginase is possible with increasing glucose concentrations. This phenomenon may be attributed to the role of glucose in enhancing growth and synthesizing primary metabolites such as enzymes (Geckil et al., 2004).

This study also revealed that different endophyte species responded differently to the various concentrations of L-asparagine and glucose to achieve optimal Lasparaginase activities. In this study, we documented that ODL4 (Ascomycoto sp.), PBS1 (Dothideomycetes sp.), PBL13 (Penicillium simplicissimum), CCL1 (Dothideomycetes sp.) and MKS1 (Fusarium oxysporum) responded well to 20, 30,10 and $40 \mathrm{mM}$ of L-asparagine, respectively. On the other hand, all isolates responded well to $5 \%$ of glucose except PBL13 ( $P$. simplicissimum), which preferred $3 \%$ of glucose. Clearly, different isolates, especially from different genus, have different nutritional requirement for optimal enzyme production (Prakasham et al., 2006), and results here contribute to the understanding of enzyme production by various species.

Comparatively, the L-asparaginase levels produced here is lower than most other non-endophytic and endophytic isolates (Prakasham et al., 2006; Kenari et al., 2011). We presumed this may be attributed to the use of minimal media in this study, which may not be suitable for all species due to the limiting nutrient availability. Nevertheless, this media eliminates the influence of all other possible carbon- or nitrogen-based nutrients, allowing the correct examination of the influence of L-asparagine or glucose on L-asparaginase activities. Other possible non-nutritional factors such as the incubation temperature, inoculum level and $\mathrm{pH}$ of media may have also influenced the inferiority of L-asparaginase activities derived in this study compared to other studies (Amena $\boldsymbol{e t}$ al., 2010; Kenari $\boldsymbol{e}$ al., 2011). Further studies on the influence of combining glucose and $L$ asparagine to induce $\mathrm{L}$-asparaginase activities can also be carried out as glucose could either enhance (Kumar $\boldsymbol{e t}$ al., 2012) or repress (Garaev and Golub, 1977) L-asparaginase activities in various isolates. The delicate combination of glucose and L-asparagine needs to be further investigated as synthesis of L-asparaginase is a catabolic regulated process and may require lesser amount of carbon compared to nitrogen source (Fraleigh et al., 1989; Geckil et al., 2005).

\section{CONCLUSION}

This study has shown that glucose and L-asparagine is able to induce Lasparaginase production in the endophytic species tested; ODL4 (Ascomycota sp.), PBS1 (Dothideomycetes sp.), PBL13 (Penicillium simplicissimum), CCL1 (Dothideomycetes sp.) and MKS1 (Fusarium oxysporum). The effect of Lasparagine was greater than glucose in inducing production of L-asparaginase (higher activities). From this study, $30 \mathrm{mM}$ of L-asparaginase may be the optimum concentration whereas for glucose, it is suggested that $5 \%$ of glucose may be appropriate although is not definite for isolate PBL13. Among these five isolates, MKS1 (Fusarium oxysporum, KM104584) produced more Lasparaginase (higher activities) in response to L-asparagine and glucose supplementation.

Acknowledgments: The authors express their gratitude to Monash University Malaysia for the funding (BCHH-SS-10-01-2012) and facilities to complete the project.

\section{REFERENCES}

Amena, S., Vishalakshi, N., Prabhakar, M., Dayanand, A., Lingappa, K., 2010. Production, purification and characterization of L-asparaginase from Streptomyces gulbargensis. Brazilian Journal of Microbiology, 41, 173-178. http://dx.doi.org/10.1590/S1517-83822010000100025

Baskar, G., Renganathan, S. ,2011. Design of experiments and artificial neural network linked genetic algorithm for modelling and optimization of $\mathrm{L}$ asparaginase production by Aspergillus terreus MTCC 1782. Biotechnology and Bioprocess Engineering 16:50-58. http://dx.doi.org/10.1007/s12257-010-0119-7. Chakravarti, R., Sahai, V., 2002. Optimization of compaction production in chemically defined production medium by Penicillium citrinum using statistical methods. Process Biochemistry, 38, 481-486. http://dx.doi:10.1016/S00329592(02)00138-3

Chow, Y.Y., Ting, A.S.Y., 2015. Endophytic L-asparaginase producing fungi from plants associated with anticancer properties. Journal of Advanced Research 6(6), 869-876. doi: http://dx.doi.org/10.1016/j.jare.2014.07.005

Eyberger, A.L., Dondapati, R., Porter, J.R., 2006. Endophyte fungal isolates from Podophyllum peltatum produce podophyllotoxin. Journal of Natural Products, 69, 1121-1124. http://dx.doi.org/10.1021/np060174f

Fraleigh, S., Bungay, H., Fiechter, A., 1989. Regulation of oxidoreductive yeast metabolism by extracellular factors. Journal of Biotechnology, 12, 185-198. http://dx.doi.org/10.1016/0168-1656(89)90040-0

Garaev, M.M., Golub, E.I., 1977. Mechanism of the effect of glucose on Lasparaginase synthesis by Escherichia coli bacteria. Mikrobiologiya, 46, 433-439. (no DOI)

Geckil, H., Gencer, S., Uckun, M., 2004. Vitreoscilla hemoglobin expressing Enterobacter aerogenes and Pseudomonas aeruginosa respond differently to carbon catabolite and oxygen repression for production of L-asparaginase: an enzyme used in cancer therapy. Enzyme and Microbial Technology, 35, 182-189. http://dx.doi.org/10.1016/j.enzmictec.2004.04.005

Geckil, H., Ates, B., Gencer, S., Uckun, M., Yilmaz, I., 2005. Membrane permeabilization of gram-negative bacteria with potassium phosphate/hexane aqueous phase system for the release of L-asparaginase: an enzyme used in cancer therapy. Process Biochemistry, 40, 573-579. http://dx.doi.org/10.1016/j.procbio.2004.01.033

Hermanto, A., Ting, A.S.Y., 2016. Comparative effect of L-asparaginase and sodium nitrate in inducing L-asparaginase prodcution by endophytic Fusarium sp. Acta Biologica Szegediensis, 60(2):145-150. (no DOI)

Imada, A., Igarasi, S., Nakahama, K., Isono, M., 1973. Asparaginase and glutaminase activities of micro-organisms. Journal of General Microbiology, 76 85-99. (no DOI)

Kenari, S.L.D., Alemzadeh, I., Maghsodi, V., 2011. Production of 1-asparaginase from Escherichia coli ATCC 11303: optimization by response surface methodology. Food and Bioproduct Processing, 89, 315-321. http://dx.doi.org/10.1016/j.fbp.2010.11.002

Kumar, K., Sunidam, Punia, S., Verma, N., 2012. Media optimization for the production of anti-leukemic enzyme L-asparaginase from E. coli K-12. Annals in Biological Research, 3, 4828-4837. (no DOI)

Kusari, S., Zuhlke, S., Spiteller, M., 2008. An endophytic fungus from Camptotheca acuminata that produces camptothecin and analogues. Journal of Natural Products, 72, 2-7. http://dx.doi.org/10.1021/np800455b

Newmann, D.J., Cragg, G.M., 2007. Natural products as sources of new drugs over the last 25 years. Journal of Natural Products, 70, 461-477. http://dx.doi.org/10.1021/np068054v

Oza, V.P., Parmar, P.P., Kumar, S., Subramanian, R.B., 2010. Anticancer properties of high purified L-asparaginase from Withania somnifera L. against acute lymphoblastic leukemia. Applied Biochemistry and Biotechnology, 160, 1833- 1840. http://dx.doi.org/10.1007/s12010-009-8667-z

Patil, M.P., Patil, R.H., Mahjeshwari, V.L., 2012. A novel and sensitive agar plug assay for screening of asparagine-producing endophhytic fungi from Aegle marmelos. Acta Biologica Szegediensis, 56, 175-177. (no DOI)

Prakasham, R.S., Rao, C.S., Rao, R.S., Lakshmi, G.S., Sarma, P.N., 2006. Lasparaginase production by isolated Staphylococcus sp-6A: design of experiment considering interaction effect for process parameter optimization. Journal of Applied Microbiology, 102.5, 1382-1391. http://dx.doi.org/10.1111/j.13652672.2006.03173.x

Raha, S.K., Roy, S.K., Dey, S.K., Chakrabarty, S.L., 1990. Purification and properties of an L-asparaginase from Cylindrocarpon obtusisporum MB-10. Biochemistry International, 21, 987-1000. (No DOI, PMID:2080924) 
Sarquis, M.I., Oliveira, E.M., Santos, A.S., Costa, G.L., 2004. Production of 1asparaginase by filamentous fungi. Memórias do Instituto Oswaldo Cruz, 99, 489-492. http://dx.doi.org/10.1590/S0074-02762004000500005

Tan, M.L., Sulaiman, S.F., Najimuddin, N., Samian, M.R., Tengku Muhammad, T.S., 2005. Endophytes: a rich source of functional metabolites. Journal of Ethnopharmacology, 96, 287-294. (No DOI)

Theantana, T., Hyde, K.D., Lumyong, S., 2009. Asparaginase production by endophytic fungi from Thai medicinal plants: cytoxicity properties. International Journal of Integrative Biology, 7, 1-8. (No DOI)

Wiyakrutta, S. Sriubolmas, N., Panphut, W., Thongon, N., Danwisetkanjana, K., Ruangrungsi, N., Meevootisom, V., 2004. Endophytic fungi with antimicrobial, anti-cancer and anti-malarial activities isolated from Thai medicinal plants. World Journal of Microbiology and Biotechnology, 20, 265272. http://dx.doi.org/10.1023/B:WIBI.0000023832.27679.a8

Zhao, J., Ma, D., Luo, M., Wang, W., Zhao, C.J., Zu, Y.G., Fu, Y.J., Wink, M.,

2014. In vitro antioxidant activities and antioxidant enzyme activities in HepG2 cells and main active compounds of endophytic fungi from pigeon pea [Cajanus cajan (L.) Millsp.]. Food Research International, 56, 243-251.

http://dx.doi.org/10.1016/j.foodres.2013.12.028 